\title{
Argumentation and interdisciplinarity: reflections from the Oxford Argumentation in Religion and Science Project
}

\author{
Sibel Erduran * D, Liam Guilfoyle, Wonyong Park, Jessica Chan and Nigel Fancourt
}

\begin{abstract}
Argumentation has emerged as a key area of research and development in science education in recent years. Simply defined, argumentation is about the justification of knowledge claims with evidence and reasons. Although there is now a vast amount of work in argumentation, much research remains to be pursued. Given the interdisciplinary nature of argumentation, the dialogue between science education and other relevant domains can potentially produce constructive research agendas that could profit argumentation research and lead to practical applications. Following an overview of the relevant interdisciplinary investigations that can be pursued in science education, the paper subsequently focuses on the interphase of science and religion. Although science education research has witnessed considerable debate about particular issues related to science and religion such as the teaching and learning of evolution and creationism, the role of argumentation remains an uncharted territory. Hence, the paper focuses on how argumentation may be explored in science and religious education in comparison. Some preliminary observations from the Oxford Argumentation in Religion and Science (OARS) Project are reported including a comparative analysis of curricula and teachers' views. Implications for interdisciplinarity in the context of argumentation in science education are discussed.
\end{abstract}

\section{Introduction}

Argumentation has emerged as a key area of research and development in science education in recent years. Several books have been published on the subject focusing on classroom-based research (e.g., Erduran, 2019; Erduran \& Jiménez-Aleixandre, 2007) and practical resources to support teaching and learning (e.g. Kelly, Erduran, Walshe, \& Guilfoyle, 2016; Sampson \& Schleigh, 2012). Simply defined, argumentation is about the justification of knowledge claims with evidence and reasons. Various definitions of argumentation have been conceptualised from different theoretical backgrounds including linguistics, philosophy, communication and socio-cultural theories (Jimenez-Aleixandre \& Erduran, 2007). A review of some key journals in science education conducted by Lin, Lin, and Tsai (2014) demonstrated that the top 10 highly cited papers published in high impact science education research journals between 1998 and 2002 included papers on argumentation. Furthermore, the review indicated that

\footnotetext{
* Correspondence: Sibel.Erduran@education.ox.ac.uk; http://www.education. ox.ac.uk/people/sibel-erduran/

Department of Education, University of Oxford, 15 Norham Gardens, Oxford OX2 6PY, UK
}

argumentation, including informal reasoning, has been studied mostly in the context of various socio-scientific issues, suggesting that these three research topics were widely considered to be closely interrelated by science educators. A more recent content analysis (Erduran, Ozdem, \& Park, 2015) of the same journals from Lin and colleagues' review, demonstrated that other themes such as "epistemic practices" and 'discourse' have been intricately linked to argumentation studies. Various aspects of science education have been addressed in argumentation studies including the role of subject knowledge (Aydeniz, 2019), the use of technology (Henderson \& Osborne, 2019), drama (Archila, 2017) and professional development of science teachers (Ozdem, Cakiroglu, Ertepinar, \& Erduran, 2017).

One of the strengths of argumentation lies in its wide applicability to other key research areas in science education, which can bring diverse forms of intradisciplinary collaboration and cross-fertilization. Recent scholarship on argumentation in science education has been active in making connections to other core research areas such as domain-specificity (Erduran, 2019; Pabuccu \& 
Erduran, 2017), curriculum reform (Erduran \& Msimanga, 2014; Marco-Bujosa, McNeill, González-Howard, \& Loper, 2017), learning progressions (Osborne et al., 2016), activity theory (Lazarou, Erduran, \& Sutherland, 2017) and nature of science (Archila, 2015; Erduran, Kaya, \& Cetin, 2017; McDonald \& McRobbie, 2012). Links have also been made to conceptual change (Erduran et al., 2017), modelling (Böttcher \& Meisert, 2011), indigenous science (Hewson \& Ogunniyi, 2011), ethics in science and technology (Lindahl, 2009) or social dynamics in science classrooms (Erduran, 2018). However, there are still considerable number of research issues that can be explored. For example, the intersections of argumentation with the fields of gender and culture, informal science learning and STEM/STEAM education are underexplored territories that are worth consideration.

In light of the vast amount of work available in argumentation in science education at present time, the purpose of this paper is not to replicate existing syntheses of research but rather to chart out a territory of potential future research. Much research remains to be pursued. Given the interdisciplinary nature of argumentation, the dialogue between science education and other relevant domains can potentially produce constructive research agendas that could profit argumentation research and lead to practical applications. For example, philosophy of science, legal theory, humanities and theology may allow for showcasing several potential research themes that could emerge as a result of such interactions.

The paper begins with a brief overview of the relevant interdisciplinary investigations that can be pursued in science education and subsequently focuses on the interphase of science and religion. Although science education research has witnessed considerable debate about particular issues related to science and religion such as the teaching and learning of evolution and creationism (e.g., Lawson \& Worsnop, 1992), the role of argumentation in this debate remains an uncharted territory. Thus, the paper focuses on how argumentation may be explored in science and religion in comparison. Some preliminary observations from a funded research and development project are presented. The OARS (Oxford Argumentation in Religion and Science) Project based at University of Oxford in England aims to engage science and religious education teachers in cross-curricular collaboration. The curriculum context for the project in England is illustrated by drawing on a comparative analysis. Some baseline qualitative data from teachers are used to illustrate emerging themes in terms of how science and religious education (RE) teachers view argumentation. Ultimately the project will produce evidence on how argumentation in science and religion are positioned in school subjects, and what support can be provided to teachers to engage in its effective teaching and learning. The implications of the paper for interdisciplinarity in argumentation are presented including how the interplay of science and religion can be explored in terms of cross-fertilisation, overlap and coherence.

\section{Interdisciplinarity and argumentation}

In a review of the role of interdisciplinarity argumentation, Crujeiras-Pérez and Jiménez-Aleixandre (2019) highlighted that "interdisciplinary thinking is understood as the capacity to integrate knowledge and modes of thinking from two or more disciplines or established areas of expertise to produce a cognitive advancement in ways that would have been impossible or unlikely through single disciplinary means" (p. 33). The authors also draw attention to the distinction of interdisciplinarity from related concepts such as 'multidisciplinarity' and 'transdisciplinarity'. Multidisciplinarity draws on perspectives from individual disciplines while acknowledging clear disciplinary boundaries, whereas transdisciplinarity focuses on addressing solely the holistic problem or issue that involves multiple disciplinary knowledge. The authors caution that many problems of the twenty-first century require interdisciplinary thinking, necessitating complex reasoning that can draw on multiple disciplinary knowledge bases.

Increasing numbers of science education researchers have also been active in introducing ideas from the philosophy of science and science studies to argumentation research in science education. There is visible interest among science education researchers in enriching conceptualisation and methodology with the findings of these disciplines on the argumentative practice in science. For example, Osborne, (2016) has recently used Hacking's six "styles of reasoning" to bring together domain-general and domain-specific aspects of scientific argumentation for educational practice. Emerging discussion on the domain-specific argumentation skills in science (Fischer, Chinn, Engelmann, \& Osborne, 2018) resembles the growing philosophical interest in the disunity of science and scientific pluralism (Park \& Song, 2019; Ribeiro \& Pereira, 2013). In the meantime, with the advent of machine learning and artificial intelligence, arguments based on probabilistic and Bayesian reasoning will also become more prevalent in scientific argumentation (Szu \& Osborne, 2012), and philosophy of science could provide innovative ideas and conceptual clarifications on these forms of reasoning. Considering that STEM professionals are increasingly relying on the reasonings made by computers as data become massive, dynamic and uncertain, such modes of reasoning and argumentation demand more attention from argumentation researchers.

Closely related to the philosophy of science, legal theory is another example of a domain that offers potential 
research agendas for argumentation research. Given that lawyers have established highly sophisticated theories of proofs, evidence and argumentation for just and efficient legal decisions, it is no surprise that legal argumentation theories can illuminate the logical and epistemic structure of argumentation in science and prompt critical reflection on it. The rich discussions on the concept of evidence, the assignment of burden of proof and so on can be applied to issues related to scientific argumentation such as the science vs. pseudoscience, UFO and intelligent design controversies (Pigliucci \& Boudry, 2014), and to socio-scientific disputes where social and political issues are entangled with science and technology. As an example, while the problem of who bears the burden of proof is a core issue in legal procedures, in scientific arguments it is often neglected. Imagine that two groups of scientists, or students, have an argument over whether one group's experimental finding is correct or not. Should the experimenters prove that all measurement was accurate and all apparatus functional, or should the critics prove that one or more of these were erroneous? If someone claims for the existence of UFOs by presenting some "photos" of them, should they then prove that these photos are genuine and that these are UFOs, or is it the arguers' burden to disprove the claim with counterevidence? Which side should the public take in the absence of conclusive evidence for both side? These questions could be of central importance in future argumentation research, particularly from the perspective of democratic citizenship (Jimenez-Aleixandre \& Erduran, 2007).

Another important way to enrich our understanding of scientific argumentation is to position it in relation to other school subjects, especially humanities such as history (Van Driel \& Van Boxtel, 2008), ethics, political theory and religious studies (Basel, Harms, Prechtl, Weiß, \& Rothgangel, 2014; Owens, Pear, Alexander, Reiss, \& Tal, 2018). How are arguments generated and justified in the fields outside the natural sciences? How are arguments in these fields different from scientific argumentation? The purpose of comparing and contrasting argumentation in science and humanities is not so much in simply identifying their similarities and differences as in understanding the nature of scientific arguments in a more indepth level. The intersections between science and other disciplines, over issues such as the origins of the universe or of life, are also a fruitful area of study to highlight the nature of scientific argumentation from a comparative perspective (e.g., Barnes, Church, \& Draznin-Nagy, 2017).

Likewise, theories of democracy, deliberation, tolerance and recognition have enormous potentials to improve and transform our way of thinking about scientific argumentation and its pedagogy. For example, how could we reach an agreement on a (socio-)scientific issue while respecting the differences among us? Erduran and Kaya's (2016) study elaborated upon the views of political theorists on the concept of deliberative democracy to draw implications for the study of scientific argumentation. Along the same line, Owens et al. (2018) recently drew on the "pedagogy of differences" to enhance students' recognition of multiple perspectives that arise in the intersection of science and religion. Making links to diverse human and social studies will bring scientific argumentation research into a more productive dialogue with the larger efforts toward democratic citizenship and social justice in education.

\section{Argumentation in science and religious education}

One useful example of inter- or cross-disciplinary opportunity for research in argumentation is at the intersection of science and religion. Of course, the intersection of the two subjects has been explored in many different ways throughout the decades (Barbour, 1966; Brooke, 1991; Humphreys, 2003; Southgate, 2011). The science-religion dialogue in the research literature has most often been high-level debate, the business of philosophers (Haack, 2013), sociologists (Evans \& Evans 2008), psychologists (Argyle \& Beit-Hallahmi, 1998), historians (Harrison, 2016) and other academics interested in teasing out the big issues and tensions generated in the intersection between science and religion. Some educators, primarily in religious education have also been concerned with the manifestation of these conflicts in schools (e.g., Cooling, 1990; Harris \& Koenig, 2006; Poole, 1990). Yet, in the midst of this rather extensive dialogue, the spotlight has not been shone on the comparison of argumentation between science and religion, in the disciplines or in school subjects.

This is partly because any discussion of the educational nexus of science and religion raises some contextual issues about the place of religions in schools-for example, the famous Scopes trial in the U.S. on the teaching of evolution (Larson, 1997)-and indeed more widely about the constitutional relationship between the state and religions (e.g., Davis \& Miroshnikova, 2013; Jackson, Miedema, Weisse, \& Willaime, 2007; Sullivan \& Beaman, 2013). Countries may have an official state religion that permeates its educational system, such as in England (Gates \& Jackson, 2014), Indonesia or Israel (Künkler \& Lerner, 2016), they may be explicitly hostile to religion, as was the case in the former Soviet Union, or indeed they may be between these positions, with different models of state religiosity, secularity or impartiality, such as France (Willaime, 2014), USA (Russo, 2012) or Turkey (Hendek, 2019). Indeed these positions may change, for example in response to increasing secularisation and religious diversity, which may necessitate more and more impartial teaching (Beyer, 2013); international terrorism, which may encourage a subject aimed at social cohesion and irenic forms of religiosity (Ghosh, 
Chan, Manuel, \& Dilimulati, 2016; Jackson, 2014; OSCE/ ODIHR, 2007); the declining influence of political atheism, notably communism, with increasing recognition of religions e.g. in Russia (Kozyrev \& Fedorov, 2007) or China (Nai, Sun, Zhang, \& Yang, 2019; Nanbu, 2008).

These different constitutional positions provide the context for the adoption of different forms of religious education. Leaving aside a separate question as to whether the state should allow and fund 'faith' schools, i.e., publicly funded schools run by religious institutions (see Jackson, 2003), the subject can be valued as nurture into a faith tradition, such as in Germany, where parents select a particular religion or denomination for $\mathrm{RE}$ lessons -typically between Catholic, Lutheran or Muslim religious education (Knauth, 2008). Alternatively, it can be an impartial study of a several religions, and possibly non-religious worldviews, such as in England (Gates \& Jackson, 2014) and advocated by some European institutions (Jackson, 2014; OSCE/ODIHR, 2007), or it may not be an explicit subject but instead a cross-curricular theme, as in France's approach since 2000 of the teaching of les faits religieux ('facts about religion') notably in history and philosophy-but also science (Willaime, 2014).

Across all these different contexts, the rationale for and aims of religious education have had to be incorporated with the wider school curriculum, including science, to ensure a coherent and balanced education for students. While on the one hand, there can be wellknown points of potential conflict, e.g., over evolution, ethical issues or the Big Bang, on the other hand, the broader educational aims can be strikingly similar. For example, here are three learning outcomes from the current Swedish curriculum, in which religious education is the study of several world religions, with the identification of the subject removed:

- In their discussions, pupils put questions and put forward views and respond to views and arguments in a way which carries the discussions forward and deepens or broadens them.

- Pupils should be given opportunities to look for answers by using different types of sources.

- Pupils can search for information about [X] and use different types of sources in a well functioning way and apply well developed and well informed reasoning about the credibility and relevance of their sources. (Skolverket, 2018, pp. 166, 188, 223)

It is not apparent to which subject these might belong. In fact, the first is from chemistry and physics, where one might not expect discussion to be prioritised. The second is also from both sciences, but the third is from religious education, showing how the critical use of 'sources' in these latter two examples is conceived as a cross-curricular process. Considering the potential overlap as well as distinction between science and religious education, further empirical investigations are needed to elicit how argumentation is positioned in school subjects and what science and religious education teachers think about the role of argumentation in their subject. An ongoing research and development project will be described next in order to where such issues of educational relevance are currently being investigated.

\section{Oxford Argumentation in Religion and Science Project}

The 3-year OARS project began in September 2018 and it involves partnership of University of Oxford and secondary schools in England teaching 11-14 years-old students. Thirty teachers from 15 schools, including a range of faith/maintained and religiously plural/religiously uniform, are currently participating in the study. A science teacher is paired with a religious education teacher in each school to ensure cross-curricular collaboration. Teacher educators who are also active researchers are working together with teachers to design and implement a professional development program. Examples to illustrate argumentation in science and religion are being chosen such that they are relevant for the purposes of the teachers. Such relevance will ensure that there is sufficient uptake by the teachers and willingness to engage in the activities of the project.

Professional development workshops involve active learning strategies such as discussions and presentations, which engage science and religious education teachers in tasks that are meaningful for their teaching practice. The overarching question driving the research is "how can cross-disciplinary teaching and learning of argumentation in science and religious education be improved?" As part of the project, numerous lines of research are being pursued including the analysis of curricula and teachers' views. In this section, some preliminary findings are reported to illustrate how OARS Project is tackling teaching of argumentation at the interphase of science and religion.

\section{Argumentation in religious education syllabi from England}

Religious education provision is not internationally uniform, but in fact is largely specific to local, national, and historical contexts (Fancourt, 2013, 2015). It is therefore rather difficult to make broad and generalised statements about religious education provision and the extent to which it provides opportunity for argumentation in classrooms. However, there are many contexts whereby religious education serves the purpose of impartially exploring and respecting a range of religions worldviews, as well as discussing issues of the nature of existence, 
ethics and morals, rather than as inculcation of a faith (Fancourt, 2013; Jackson, 2014). For the purposes of exploring opportunities for argumentation in the curriculum and its overarching objectives, OARS Project focused on a few local authorities within England as an example.

When examining the curriculum documents or precisely, the local agreed syllabi that guide religious education provision at Key Stage 3 in England (ages 11-14), we performed a content analysis that searched for commands which fit our theoretical understanding of argumentation from the literature. (Note that there is no national curriculum in religious education in England but rather there are regional documents that are referred to as 'syllabi'.) This analytical process involved identifying specific references to argumentation (e.g., "argument" or "argue"), reasonable synonyms (e.g., "debate" or "reasoned opinion"), or components of argumentation (e.g., "express insights", "weigh up", or "interpret and evaluate"). On doing so, we found the selected religious education syllabi to be almost brimming with language that resonates with the project's definition of argumentation. Table 1 shows a small range of statements from two agreed syllabi at Key Stage 3.

In total, there were 82 references in the Leicestershire Agreed Syllabus (2016) and 16 such references in the Oxfordshire Agreed Syllabus (2015), both at Key Stage 3 level. Religious education under the direction of such curriculum documents, is clearly a fertile ground for the teaching and learning of argumentation, given the many explicitly-written pedagogic objectives and implications that manifested the broad meaning or focused definition of argumentation. These apparent elements of argumentation stipulated in the agreed syllabi confirmed that argumentation is vital as a learning process, which at the same time reflects the overarching objectives of the curriculum and the nature of the subject.

The document analysis showed that argumentation is manifested very widely in various Key Stage 3 religious education agreed syllabi in England. There were two additional striking features of these documents. The first is that these documents placed a particular emphasis on respecting a plurality of arguments or positions and discouraging any sort of persuasion by the teacher or between students (see Table 1). This is likely the reason for the second striking feature, which is that there was no indication of how arguments should be constructed or any criteria against which arguments should be evaluated. For instance it was unclear what might count as 'reasons' or 'balance'. (Please note that the word 'pupil' has been kept where the occurrence was from an original source. Otherwise the word 'student' is used to refer to individuals enrolled in secondary schooling.)

\section{Argumentation in science curricula from England}

Argumentation and related concepts have been a part of the English science curriculum for a few decades. Over a decade ago, La Velle and Erduran (2007) traced the history of the science curricula in England and how argumentation was placed in the curriculum documents from different examination boards. More recently, as part of Project OARS we examined contemporary science curriculum documents. One outcome of our investigations was that in the 2014 National Curriculum for Science in England at Key Stage 3 (ages 11-14), there is a difference in the volume (i.e. 11 instances) and nature of phrases associated with arguments or argumentation where many of these phrases merely allude to an understanding that could be tentatively linked to argumentation. The qualitative differences seem even more striking. The 2014 National Curriculum for Science states that

Through the content across all three disciplines, pupils should be taught to:

- Understand that scientific methods and theories develop as earlier explanations are modified to take account of new evidence and ideas, together with the importance of publishing results and peer review...

- Present reasoned explanations, including explaining data in relation to predictions and hypotheses.

- Evaluate data, showing awareness of potential sources of random and systematic error. (Department for Education (DfE), 2014, p. 201)

Table 1 Argumentation in example religious education syllabi in England

\begin{tabular}{ll}
\hline Leicestershire County Council (2016) & Oxfordshire County Council (2015) \\
"Engage pupils in systematic enquiry ... . appraise varied responses & "... does not seek to impose [but to] question and explore \\
to these questions, as well as develop their own responses" (p. 6) & their own and others' understanding of life" (p. 10) \\
"interpret and evaluate texts, sources of wisdom and authority & "formulate reasoned opinions/arguments in relation to \\
and over evidence" (p. 6) & controversial issues and truth" (p. 11) \\
"Explore and express insights ... that are well-informed ... & "... develop their evaluative skills, showing reasoned and \\
using reasoning" (p. 70) & $\begin{array}{l}\text { balanced viewpoints when considering their own and } \\
\text { others' responses" (p. 32) }\end{array}$ \\
"Give an account of God's existence using a rational argument. & "... respond sensitively and with reasoned argument to \\
Offer reasons as to why we do or do not need to prove & religious beliefs and concepts" (p. 34) \\
God's existence" ( $\mathrm{p} .74)$ & \\
\hline
\end{tabular}


The first point above, that students should understand the methods of science and how scientific explanation evolves, is undoubtedly important. It is relevant here because it is through argumentative processes that knowledge develops; that is, knowledge claims are offered with supporting evidence, warrants and backing, to be challenged by rebuttals and counterarguments with new or additional evidence (Lawson, 2003). Collectively, knowledge which is accepted evolves through these successive arguments (Lawson, 2003). Of the three points, only one (the middle) is directing students to construct arguments. "Present reasoned explanations" could be considered as synonymous with "present an argument". The verb 'present' still stands in contrast to the verbs used in religious education syllabi documents, where students are expected to 'formulate' arguments. The final extract, that students should evaluate data and show awareness of error, could be considered to be part of argumentative reasoning as it may facilitate the construction of rebuttals or counter-arguments.

Overall, the preliminary findings suggest that argumentation is more explicitly promoted in the religious education syllabi than the science curriculum in England. Despite the limitations of the current science curriculum at Key Stage 3 in England, past iterations (La Velle \& Erduran, 2007), and more recent curriculum projects in other parts of the world including in Ireland (e.g., Kelly \& Erduran, 2019) and Taiwan (e.g., Yeh, Erduran, \& Hsu, 2019), provide examples of how science curricula can advocate effective teaching and learning of argumentation in science. However, the ultimate success in the implementation of both the science and religious education curricula will depend on how teachers approach argumentation. For this reason, OARS Project is also investigating how teachers conceptualise argumentation in their own subject as well as the others'.

\section{Science and religious education teachers' views of argumentation}

At the onset of the project, findings suggest that there are both similarities and differences in terms of how religious education and science teachers view argumentation. While both religious education and science teachers view argumentation as a way of justifying claims, science teachers emphasise distinguishing right from wrong while the religious education teachers tend to focus on distinguishing better or worse arguments:

Religious education does not have a definitive answer but arguments to support a view.

(Religious education teacher)
As scientists we need to be able to decide which theories are correct and most likely to accurately represent what is happening. (Science teacher)

Similarly, data from science teachers suggest that they consider the importance of testing in science. They refer to an 'objective' reality beyond the individual experience. On the other hand, religious education teachers refer to claims of truth that cannot necessarily be tested or need not refer to a reality beyond the individual's experience of this reality.

\section{Truth claims are based on their own or others' worldview. (Religious education teacher)}

It's important for students to realise there are different views, but also that we can arrive at answers that are worth more than simple opinions through examining and testing evidence. (Science teacher)

When asked why topics from religious education (if science teacher) or from science (if religious education teacher) the other subject needs to be considered in their lessons, teachers indicate that there is need for crosscurricular interaction for various reasons including overlapping concerns such as ethics and history of the subject:

Overlap in lots of topics e.g. creation, environment, medical ethics. (Religious education teacher)

As a different perspective and to show pupils how overlapping ideas are. (Religious education teacher)

History of science is often affected by religious beliefs. [...] (Science teacher)

The ongoing professional development programme is aiming to facilitate further conversation between the science and religious education teachers so as to expose further the issues that emerge in their collaborations as well as their lessons in teaching argumentation. Answering the ultimate question of OARS Project (i.e. how crossdisciplinary teaching and learning of argumentation in science and religious education be improved) will help clarify the nature of constructive research and development agendas. In the next section, some potential avenues for inter- and cross-disciplinary research are considered.

\section{Implications of inter- or cross-disciplinary argumentation research}

Although it is not yet possible to empirically demonstrate effective modes of interaction about research and development on argumentation in science and religious education, there are at least three potential theoretical modes: (a) cross-fertilisation, where either subject can 
learn from the strengths of the other; (b) overlap, where students require the skills to tackle issues that may draw upon arguments from both subject areas, and (c) the beginning of a coherent view of argumentation across the curriculum, which could extend to other school subjects such as history and mathematics.

\section{Cross-fertilisation}

The process of collaborative work between the subject areas of science and religious education, whether in research or professional development, could be fruitful in terms of what can be learned from the other subject. The place of debate, discussion, and argument formation is so evident within the religious education syllabi that the classroom pedagogy associated with these activities is likely to be the 'bread and butter' of the religious education teacher in ways it is not for the science teacher (see ter Avest, Jozsa, Knauth, Rosón, \& Skeie, 2009). Science education could learn much from the ways that these activities are initiated and facilitated, particularly in managing a plurality of perspectives. Further, arguments in religious education utilise more than just empirical evidence, but draw on values, ethics, and morals as reasons too. Though socio-scientific issues have been circulating science curricula for some time (e.g. Zeidler \& Sadler, 2008), research has noted the tendency for valueladen discussions to be avoided in science education (Forsyth, 2017).

Yet, when it comes to the construction of arguments in religious education education and the evaluation of arguments, we noted that structure and guidance was limited from both curriculum and literature in religious education. Religious education could benefit from drawing upon the structures provided for argumentation in science education research. Reciprocally, the adoption of such structures into religious education will likely require some adaption to account for the place of reasons beyond empirical evidence (i.e., values or foundational beliefs), as well as a wider definition of argumentation and how it operates in humanity subjects that are traditionally perceived in sharp contrast to science. This will be beneficial for science education, particularly in dealing with debates on socio-scientific issues.

\section{Overlap}

There are a range of issues where an individual will be exposed to both religious and scientific arguments, or will want to draw on information from both religion and science (e.g. abortion, end-of-life decisions, genetic engineering, evolution). Such issues, which may arise in either science or religious education classes, would benefit from the individual's ability to discern religious arguments from scientific ones and be able to synthesise these into their own coherent argument for the purposes of decision making. This is a goal of both subject areas as they intend to develop an informed citizenry that is both scientifically and religiously literate (Department for Education (DfE), 2014; Leicestershire County Council, 2016). It is, arguably, insufficient for an individual to learn how to generate and evaluate arguments in the subjects separately without considering the other discipline when so many issues upon which they may need to decide will be interdisciplinary. Inter- or cross-disciplinary research and professional development is needed to better support the teaching and learning of argumentation for these sorts of 'overlapping' issues.

\section{Coherence}

Our focus on religious education and science serves as an example of work which may generate benefits by way of understanding argumentation in a coherent manner across the whole curriculum or different disciplines. There is a need for domain specificity in terms of argumentative reasoning (Kienhues, Thomm, \& Bromme, 2018), but so too is there a need to explore how argumentation can permeate across the school curriculum so that what happens in one domain can be related to others (Goldman, Ko, Greenleaf, \& Brown, 2018). Such an aim for crosscurricular coherence is a sufficient aim in itself.

\section{Conclusions}

The paper demonstrates that science education research has given extensive focus to argumentation over the past two decades (e.g. Erduran et al., 2015). Though there may be some disagreement, the models proposed for the construction and evaluation of arguments are rather similar and well structured (e.g., Sampson \& Blanchard, 2012). These have generally drawn upon literature concerning philosophy, rhetoric, and reasoning (Toulmin, 1958; Walton, 1996). Despite this increasingly popular focus in science education literature and the implementation via professional development (e.g., Ozdem et al., 2017), as our illustration of the contemporary English science curriculum illustrates, the explicit inclusion of argumentation can be limited.

Although argumentation in science education has emerged as a point of interest over the last decade (Lee, $\mathrm{Wu}, \&$ Tsai, 2009; Lin et al., 2014), its role in religious education has been less investigated. There is some recent research from German and Austrian researchers which has focused on the overlap between science and religion, in the context of the faith-choice based model of religious education (Basel, Harms, \& Prechtl, 2013; Basel et al., 2014; Schmidt, Grube, \& Rothgangel, 2017). Instead, much research in religious education has tended to focus on establishing classroom dialogue between those of different views, in the light of demands for social cohesion (e.g., Iversen, 2018; ter Avest et al., 2009). 
Research on argumentation is broadly related students' epistemic understanding of religion and science, and the overlap and boundaries between them in schools. (Billingsley, Nassaji, Fraser, \& Lawson, 2018; Taber, Billingsley, Riga, \& Newdick, 2011). However, in addition to epistemic views students should also be guided to adopt the ways scientists ask questions and approach a problem within the discipline, i.e. learning to think like a scientist. This adoption of ways of thinking specific to the subject, or more generally, disciplinary thinking skills, are equally important to studying religion. However, those researchers have underscored the importance of students' understanding of the sorts of questions that are asked in science compared to religion, and how claims are supported in both science and religion. When thinking about such interdisciplinary questions, it would be important to be able to competently draw on knowledge from both science and religious studies, as well as to understand the similarities or differences how reasoning operates in either. This serious and deep-thinking process can only be accessed by understanding the nature of the claims, evidence, and reasons underpinning the claims from each subject. The examination of various views and evidence is conceived as argumentation in learning.

Ultimately, the comparative study of argumentation in an interdisciplinary fashion will serve to deepen our understanding both in terms of what is uniquely scientific, but also potentially in underexplored areas such as how religious arguments work and how they might relate or not to scientific arguments. Although argumentation has increased in popularity in the science education literature in recent years, much work remains to be done in terms of how it may relate to traditionally disparate school subjects such as religious education. Future research and development efforts on argumentation in science education will benefit from explorations and investigations on how argumentation can be navigated across different school subjects.

\section{Acknowledgements}

The authors acknowledge funding from the Templeton World Charity Foundation to OARS Project (Grant Number TWCF0238) awarded to Sibel Erduran as the Principal Investigator.

\section{Authors' contributions}

SE - conceptualisation of the paper, literature review on argumentation in science education, conceptualisation of the funded project. LG - analysis and interpretation of religious education curricula; contrast with science education curriculum. WP - literature review on interdisciplinarity. JC analysis and interpretation of religious education curricula. NF - references on religious education, stylistic matters on religious education literature. All authors read and approved the final manuscript.

\section{Funding}

Templeton World Charity Foundation to OARS Project (Grant Number TWCF0238)
Availability of data and materials

Open access as per invitation to contribute to special issue.

Competing interests

The authors declare that they have no competing interests.

Received: 25 April 2019 Accepted: 22 July 2019

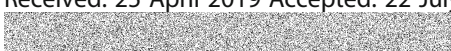

\section{References}

Archila, P. A. (2015). Using history and philosophy of science to promote students' argumentation: A teaching-learning sequence based on the discovery of oxygen. Science \& Education, 24(9-10), 1201-1226.

Archila, P. A. (2017). Using drama to promote argumentation in science education: The case of "should've". Science \& Education, 26(3-4), 345-375.

Argyle, M., \& Beit-Hallahmi, B. (1998). The psychology of religious behaviour, belief and experience. London: Routledge.

Aydeniz, M. (2019). Teaching and learning chemistry through argumentation. In S. Erduran (Ed.), Argumentation in chemistry education: Research, policy and practice, (pp. 11-31). London: Royal Society of Chemistry.

Barbour, I. (1966). Issues in science and religion. London: SCM Press.

Barnes, R. M., Church, R. A., \& Draznin-Nagy, S. (2017). The nature of the arguments for creationism, intelligent design, and evolution. Science \& Education, 26(1-2), 27-47.

Basel, N., Harms, U., \& Prechtl, H. (2013). Analysis of students' arguments on evolutionary theory. Journal of Biological Education. https://doi.org/10.1080/ 00219266.2013 .799078 .

Basel, N., Harms, U., Prechtl, H., Weiß, T., \& Rothgangel, M. (2014). Students arguments on the science and religion issue: The example of evolutionary theory and genesis. Journal of Biological Education, 48(4), 179-187.

Beyer, P. (2013). Deprivileging religion in a post-Westphalian state: Shadow establishment, organization, spirituality and freedom in Canada. In W. Sullivan, \& L. Beaman (Eds.), Varieties of religious establishment, (pp. 75-92). London: Routledge.

Billingsley, B., Nassaji, M., Fraser, S., \& Lawson, F. (2018). A framework for teaching epistemic insight in schools. Research in Science Education, 48, 1115-1131.

Böttcher, F., \& Meisert, A. (2011). Argumentation in science education: A modelbased framework. Science \& Education, 20(2), 103-140.

Brooke, J. H. (1991). Science and religion: Some historical perspectives. Cambridge: Cambridge University Press.

Cooling, T. (1990). Science and religious education: Conflict or co-operation? British Journal of Religious Education, 13(1), 35-42.

Crujeiras-P., B. \& Jimenez-Aleixandre, M. P. (2019). Interdisciplinarity and argumentation in chemistry educaiton. In S. Erduran (Ed.), Argumentation in Chemistry Education: Research, Policy and Practice, pp32-61. London: Royal Society of Chemistry

Davis, D., \& Miroshnikova, E. (Eds.) (2013). The routledge international handbook of religious education. Abingdon: Routledge.

Department for Education (DfE) (2014). The national curriculum in England framework document. London: Department for Education.

Erduran, S. (2018). Toulmin's argument pattern as a "horizon of possibilities" in the study of argumentation in science education. Cultural Studies of Science Education, 13(4), 1-9.

Erduran, S. (2019). Argumentation in chemistry education: Research, policy and practice. London: Royal Society of Chemistry.

Erduran, S., \& Jiménez-Aleixandre, M. P. (Eds.) (2007). Argumentation in science education: Perspectives from classroom-based research. Dordrecht: Springer.

Erduran, S., \& Kaya, E. (2016). Scientific argumentation and deliberative democracy: An incompatible mix in school science? Theory Into Practice, 55(4), 302-310.

Erduran, S., Kaya, E., \& Cetin, P. S. (2017). Consolidation of conceptual change, argumentation, models and explanations. In T. G. Amin, \& O. Levrini (Eds.), Converging perspectives on conceptual change: Mapping an emerging paradigm in the learning sciences, (pp. 153-162). London: Routledge.

Erduran, S., \& Msimanga, A. (2014). Science curriculum reform in South Africa: Lessons for professional development from research on argumentation in science education. Education as Change, 18(sup1), S33-S46.

Erduran, S., Ozdem, Y., \& Park, J.-Y. (2015). Research trends on argumentation in science education: A journal content analysis from 1998-2014. International Journal of STEM Education, 2(5), 1-12. 
Evans, J. H. \& Evans, M., S. (2008). Religion and science: beyond the epistemological conflict narrative. Annu. Rev. Sociol. 34, 87-105.

Fancourt, N. (2013). Religious education across Europe: Contexts in policy scholarship. In J. Everington, G. Skeie, I. ter Avest, \& S. Miedema (Eds.) Exploring context in religious education research. Waxmann: Münster.

Fancourt, N. (2015). Re-defining 'learning about religion' and 'learning from religion': A study of policy change. British Journal of Religious Education, 37(2), 122-137.

Fischer, F., Chinn, C. A., Engelmann, K., \& Osborne, J. (Eds.) (2018). Scientific reasoning and argumentation: The roles of domain-specific and domain-general knowledge. London: Routledge.

Forsyth, A. (2017). Considering the nature of science and religion in science education. In M. B. Etherington (Ed.), What teachers need to know: Topics in diversity and inclusion, (pp. 285-300). Oregon: Wipf \& Stock.

Gates, B., \& Jackson, R. (2014). Religion and education in England. In M. Rothgangel, R. Jackson, \& M. Jäggle (Eds.), Religious education in Europe. Part 2: Western Europe, (pp. 65-98). Vienna: Vienna University Press.

Ghosh, R., Chan, W., Manuel, A., \& Dilimulati, M. (2016). Can education counter violent religious extremism? Canadian Foreign Policy Journal, 23(2), 117-133. https://doi.org/10.1080/11926422.2016.1165713.

Goldman, S. R., Ko, M.-L. M., Greenleaf, C., \& Brown, W. (2018). Domain-specificity in the practices of explanation, modeling, and argument in the sciences. In F. Fischer, C. A. Chinn, K. Engelmann, \& J. Osborne (Eds.), Scientific reasoning and argumentation: The roles of domain-specific and domain-general knowledge. London: Routledge.

Haack S. (2013). The 'ethics of belief' reconsidered. In H. Rydenfelt, \& S. Pihlström S. (Eds), William James on Religion. Philosophers in Depth. London: Palgrave Macmillan.

Harris, P. L., \& Koenig, M. A. (2006). Trust in testimony: How children learn about science and religion. Child Development, 77(3), 505-524.

Harrison, P. (2016). Religion, scientific naturalism and historical progress. In D. A. Yerxa (Ed.), Religion and innovation: Antagonists or partners? London: Bloomsbury Academic.

Hendek, A. (2019). Country report: Turkey. British Journal of Religious Education, $41(1), 8-13$.

Henderson, B., \& Osborne, J. (2019). Using computer technology to support the teaching and learning of argumentation in chemistry. In S. Erduran (Ed.), Argumentation in chemistry education: Research, policy and practice, (pp. 79-105). London: Royal Society of Chemistry.

Hewson, M. G., \& Ogunniyi, M. B. (2011). Argumentation-teaching as a method to introduce indigenous knowledge into science classrooms: Opportunities and challenges. Cultural Studies of Science Education, 6(3), 679-692.

Humphreys, C. (2003). The miracles of exodus: A scientist's discovery of the extraordinary natural causes of the biblical stories. San Francisco: Harper Collins.

Iversen, L. L. (2018). From safe spaces to communities of disagreement. British Journal of Religious Education. https://doi.org/10.1080/01416200.2018.1445617.

Jackson, R. (2003). Should the state fund faith based schools? A review of the arguments. British Journal of Religious Education, 25(2), 89-102.

Jackson, R. (2014). Signposts: Policy and practice for teaching about religions and non-religious worldviews in intercultural education. Strasbourg: Council of Europe.

Jackson, R., Miedema, S., Weisse, W., \& Willaime, J.-P. (Eds.) (2007). Religion and education in Europe: Developments, contexts and debates. Münster: Waxmann.

Jimenez-Aleixandre, M. P., \& Erduran, S. (2007). Argumentation in science education: An overview. In S. Erduran, \& M. P. Jimenez-Aleixandre (Eds.), Argumentation in science education, (pp. 3-28). Dordrecht: Springer.

Kelly, R., \& Erduran, S. (2019). Understanding aims and values of science: Developments in the junior cycle specifications on nature of science and preservice science teachers' views in Ireland. Irish Educational Studies, 38(1), 43-70.

Kelly, R., Erduran, S., Walshe, G., \& Guilfoyle, L. (2016). STEP into science: Engaging students, teachers and parents in scientific debates. CPD and lesson resource pack. Limerick: University of Limerick.

Kienhues, D., Thomm, E., \& Bromme, R. (2018). Specificity reloaded: How multiple layers of specificity influence reasoning in science argument evaluation. In F. Fischer, C. A. Chinn, K. Engelmann, \& J. Osborne (Eds.), Scientific reasoning and argumentation: The roles of domain-specific and domain-general knowledge, (pp. 251-270). London: Routledge.

Knauth, T. (2008). "Better together than apart": religion in school and lifeworld of students in Hamburg, in T. Knauth, D.-P. Jozsa, G. Bertram-Troost, \& J. Ipgrave, (Eds.), Encountering Religious Pluralism in School and Society: A Qualitative Study of Teenage Perspectives in Europe, (pp. 207-245). Munster: Waxmann.
Kozyrev, F., \& Fedorov, V. (2007). Religion and education in Russia: Historical roots, cultural context and recent developments. In R. Jackson, S. Miedema, W. Weiße, \& J.-P. Willaime (Eds.), Religion and education in Europe: Developments, contexts and debates, (pp. 133-158). Münster: Waxmann.

Künkler, M., \& Lerner, H. (2016). A private matter? Religious education and democracy in Indonesia and Israel. British Journal of Religious Education, 38(3), 279-307.

La Velle, L. B., \& Erduran, S. (2007). Argument and developments in the science curriculum. School Science Review, 88(324), 31.

Larson, E. (1997). Summer for the gods: The scopes trial and America's continuing debate over science and religion. New York: Basic Books.

Lawson, A. E. (2003). The nature and development of hypothetico-predictive argumentation with implications for science teaching. International Journal of Science Education, 25(11), 1387-1408.

Lawson, A. E., \& Worsnop, W. A. (1992). Learning about evolution and rejecting a belief in special creation: Effects of reflective reasoning skill, prior knowledge, prior belief and religious commitment. Journal of Research in Science Teaching, 29(2), 143-166.

Lazarou, D., Erduran, S., \& Sutherland, R. (2017). Argumentation in science education as an evolving concept: Following the object of activity. Learning, Culture and Social Interaction, 14, 51-66.

Lee, M. H., Wu, Y. T., \& Tsai, C. C. (2009). Research trends in science education from 2003 to 2007: A content analysis of publications in selected journals. International Journal of Science Education, 31(15), 1999-2020.

Leicestershire County Council (2016). Leicestershire religious literacy for all: The agreed syllabus for religious education 2016-2012. Leicestershire: County Council.

Lin, T.-C., Lin, T.-J., \& Tsai, C.-C. (2014). Research trends in science education from 2008 to 2012: A systematic content analysis of publications in selected journals. International Journal of Science Education, 36(8), 1346-1372.

Lindahl, M. G. (2009). Ethics or morals: Understanding students' values related to genetic tests on humans. Science \& Education, 18(10), 1285-1311.

Marco-Bujosa, L. M., McNeill, K. L., González-Howard, M., \& Loper, S. (2017). An exploration of teacher learning from an educative reform-oriented science curriculum: Case studies of teacher curriculum use. Journal of Research in Science Teaching, 54(2), 141-168.

McDonald, C. V., \& McRobbie, C. J. (2012). Utilising argumentation to teach nature of science. In B. J. Fraser, K. Tobin, \& C. J. McRobbie (Eds.), Second international handbook of science education, (pp. 969-986). Dordrecht: Springer Netherlands.

Nai, P., Sun, J., Zhang, Y., \& Yang, G. (2019). Religious education legislation in an atheist state: Towards a typology and policy analysis for contemporary China. British Journal of Religious Education. https://doi.org/10.1080/01416200.2019.1571994.

Nanbu, H. (2008). Religion in Chinese education: From denial to cooperation. British Journal of Religious Education, 30(3), 223-234. https://doi.org/10.1080/ 01416200802170151.

Osborne, J. (2016). Styles of scientific reasoning: What can we learn from looking at the product, not the process, of scientific reasoning? In Scientific reasoning and argumentation: The roles of domain-specific and domain-general knowledge. London: Routledge.

Osborne, J., Henderson, J. B., MacPherson, A., Szu, E., Wild, A., \& Yao, S. (2016). The development and validation of a learning progression for argumentation in science. Journal of Research in Science Teaching, 53(6), 821-846.

OSCE/ODIHR (2007). Toledo guiding principles on teaching about religions and beliefs in public schools. Warsaw: ODIHR.

Owens, D. C., Pear, R. S. A., Alexander, H. A., Reiss, M. J., \& Tal, T. (2018). Scientific and religious perspectives on evolution in the curriculum: An approach based on pedagogy of difference. Research in Science Education, 48(6), 1171-1186.

Oxfordshire County Council (2015). The Oxfordshire agreed syllabus for religious education 2015-2020. Oxfordshire: County Council.

Ozdem, Y., Cakiroglu, J., Ertepinar, H., \& Erduran, S. (2017). The pedagogy of argumentation in science education: Science teachers' instructional practices. International Journal of Science Education, 39(11), 1443-1464.

Pabuccu, A., \& Erduran, S. (2017). Beyond rote learning in organic chemistry: The infusion and impact of argumentation in tertiary education. International Journal of Science Education, 39(9), 1154-1172.

Park, W., \& Song, J. (2019). Between realism and constructivism: A sketch of pluralism for science education. In E. Herring, K. Jones, K. Kiprijanov, \& L. 
Sellers (Eds.), The past, present and future of integrated history and philosophy of science, (pp. 228-247). London: Routledge.

Pigliucci, M., \& Boudry, M. (2014). Prove it! The burden of proof game in science vs. pseudoscience disputes. Philosophia, 42(2), 487-502.

Poole, M. (1990). A guide to science and belief. Oxford: Lion.

Ribeiro, M. A. P., \& Pereira, D. C. (2013). Constitutive pluralism of chemistry:

Thought planning, curriculum, epistemological and didactic orientations. Science \& Education, 22(7), 1809-1837.

Russo, C. (Ed.) (2012). Religion in schools. Thousand Oaks: Sage.

Sampson, V., \& Blanchard, M. R. (2012). Science teachers and scientific argumentation: Trends in views and practice. Journal of Research in Science Teaching, 49(9), 1122-1148.

Sampson, V., \& Schleigh, S. (2012). Scientific argumentation in biology: 30 classroom activities. Arlington: NSTA Press.

Schmidt, H., Grube, D. \& Rothgangel, M. (2017). The relevance of prior content knowledge regarding bioethical dilemmas: Religious education in dialogue with empirical studies of educational psychology. Journal of Empirical Theology, 30(7), 68-86.

Skolverket (2018). Curriculum for the compulsory school, preschool class and schoolage educare. Revised 2018. Stockholm: Skolverket [English version]. Retrieved from https://www.skolverket.se/download/18.6bfaca41169863e6a65d4df/1553 968064187/pdf3984.pdf.

Southgate, C. (2011). God, humanity, and the cosmos: A textbook in science and religion. London: Bloomsbury Publishing.

Sullivan, W., \& Beaman, L. (Eds.) (2013). Varieties of religious establishment. London: Ashgate.

Szu, E., \& Osborne, J. (2012). Scientific reasoning and argumentation from a Bayesian perspective. In M. S. Khine (Ed.), Perspectives on scientific argumentation: Theory, practice and research, (pp. 55-71). Dordrecht: Springer.

Taber, K. S., Billingsley, B., Riga, F., \& Newdick, H. (2011). Secondary students' responses to perceptions of the relationship between science and religion: Stances identified from an interview study. Science Education, 95, 1000-1025.

ter Avest, I., Jozsa, D.P., Knauth, T., Rosón, J., \& Skeie, G. (Eds.) (2009). Dialogue and conflict on religion: Studies of classroom interaction in European countries. Münster: Waxmann

Toulmin (1958). Uses of argument. Cambridge: Cambridge University Press.

Van Driel, J., \& Van Boxtel, C. (2008). Historical reasoning: Towards a framework for analyzing students' reasoning about the past. Educational Psychology Review, 20(2), 87-110

Walton, D. (1996). Argumentation schemes for presumptive reasoning. Mahweh: Lawrence Erlbaum Associates.

Willaime, J.-P. (2014). Religion and education in French schools. In M. Rothgangel, R. Jackson, \& M. Jäggle (Eds.), Religious education in Europe. Part 2: Western Europe, (pp. 99-120). Vienna: Vienna University Press.

Yeh, Y., Erduran, S., \& Hsu, Y. S. (2019). Investigating coherence on nature of science in the science curriculum documents from Taiwan. Science \& Education, 28(3-5), 291-310.

Zeidler, D. L., \& Sadler, T. D. (2008). Social and ethical issues in science education: A prelude to action. Science \& Education, 17(8, 9), 799-803.

\section{Publisher's Note}

Springer Nature remains neutral with regard to jurisdictional claims in published maps and institutional affiliations.

\section{Submit your manuscript to a SpringerOpen ${ }^{\circ}$ journal and benefit from:}

- Convenient online submission

- Rigorous peer review

- Open access: articles freely available online

- High visibility within the field

- Retaining the copyright to your article

Submit your next manuscript at $\boldsymbol{\nabla}$ springeropen.com 